\title{
Web-Based Integrated CSR Reporting: An Empirical Analysis
}

\author{
Luisa Bosetti*
}

\begin{abstract}
Nowadays, corporate success depends on the ability to integrate social and environmental concerns into business operations and strategies. Transparency is also fundamental to an effective interaction with a variety of stakeholders, especially for companies operating in global markets. The Internet can significantly contribute to the widespread dissemination of complete and timely information on a company's activities and performance. Combining theoretical and empirical research, this article focuses on web-based integrated CSR reporting and presents an empirical investigation whose results emphasise the necessity to improve online communication on sustainability matters, including in CSR-oriented companies.
\end{abstract}

Keyword: Integrated CSR; Sustainability; Web-Based Reporting; Stakeholder Dialogue; Non-Financial Information; Content Analysis; Disclosure Index; Global Markets

\section{Integrated CSR and Evolution of Corporate Communication}

This century has witnessed tremendous progress in corporate communication, involving both the content of information and the means to reach a company's stakeholders.

In the past, when shareholder orientation dominated corporate governance decisions (Friedman, 1970), a company's disclosures were mainly focused on financial aspects, with the purpose of meeting the information needs of shareholders and other investors. This approach has gradually been replaced, specifically in firms implementing a broader concept of sustainable governance and stakeholder relationship management based on corporate social responsibility (CSR) (Brondoni, 2003; Gnecchi, 2006; Salvioni \& Astori, 2013; Klettner et al., 2014). CSR entails the voluntary integration of economic, ethical, social and ecological expectations into corporate strategies and daily operations (Clarkson, 1995; Carroll, 1999; Commission of the European Communities, 2001; Henriques and Richardson, 2004; Crane, 2008; Mosca \& Civera, 2017). Moreover, CSR stresses the link between value creation for all stakeholders (Freeman, 1984; European Commission, 2011; Mosca et al., 2015) and a company's success in the long term.

Consequently, corporate reporting has widened its scope to provide a transparent representation of how companies reconcile social well-being and environmental

* Associate Professor of Business Administration, University of Brescia (luisa.bosetti@unibs.it) 
protection with the pursuit of profitability. At the same time, the variety and amount of information that firms divulge to their stakeholders has progressively increased, also because under pressure from policymakers, stock exchange commissions and organisations engaged in the promotion of non-financial communication (Eccles \& Krzus, 2010; Eccles \& Serafeim, 2011; Salvioni \& Bosetti, 2014a; Cantino \& Cortese, 2017).

Moreover, the evolution of corporate reporting is strongly connected to the spread of innovative technologies supporting timely and efficient communication between firms and a multitude of stakeholders located all over the world. Companies are presently being stimulated to seize the opportunities created by the Internet and strive to improve online reporting.

Combining theory and practice, this article focuses on how companies use their websites to disseminate information on integrated CSR.

\section{Web-Based Reporting}

The disclosure of corporate information is a driver of resource allocation in capital markets (Elsayed et al., 2010). As the information divulged can affect shareholders' and other stakeholders' evaluations of the way a company faces economic, social and environmental issues, it can also influence their decision-making processes.

Nowadays, companies operate in a barrier-free environment where the importance of information is amplified, because it can potentially reach any audience all over the world. Indeed, globalisation poses new challenges to firms (Brondoni, 2014) by broadening their relationships and requiring transparency, accountability and innovative forms of stakeholder dialogue (Salvioni, 2003; Bisio, 2017; Cassano, 2017); in response to this, technological advancement stimulates the recourse to means of communication other than the traditional hard-copy reports (Oyelere \& Kuruppu, 2016).

In recent years, the Internet has become increasingly important for the dissemination of financial and non-financial information, thanks to the wide range of advantages it provides to both companies and their publics (Lambin, 2014). The Internet has global reach and is versatile, dynamic, interactive, speedy and decentralised (Xiao et al., 2004); moreover, it mixes multiple media, including text, audio, graphics, animation and video (Weare \& Lin, 2000; Sushila \& Amol, 2016) and permits the transfer of complete and timely information (Aly et al., 2010).

$\square$ Hypermedia is one of the most significant features of web-based
communication. Since an Internet page consists of single objects
connected through hyperlinks, users have the freedom to choose what to
read and in what sequence. Therefore, companies should learn to govern
hypermedia in order to guide user choices and lead users towards the
most relevant content of the website.

Developed with the aim of exploiting the Internet's technological features, webbased reporting (also called Internet-based disclosure and online reporting) consists in divulging qualitative and quantitative information through a company's website, 
combining written text, visual content, audio and video records and live broadcasts in a flexible way. Web-based reporting also relies on the availability of online tools that facilitate and accelerate navigation of a company's website. Using the Internet as a means of communication between a company and its stakeholders may also strengthen instantaneous interactions based on the exchange of questions and feedbacks.

Due to its technological nature, web-based reporting has been described as a "sophisticated" communication (Debreceny et al., 2002) that comprises interactive tools for examining the information disclosed (Bozcuk, 2012). In this regard, an early study promoted by the International Accounting Standards Committee distinguished three stages in the evolution of business reporting on the Internet (IASC, 1999). In the first stage, companies turn their printed reports into "electronic paper", so that the online disclosure is a simple duplication of hard-copy financial statements, usually by means of a PDF file. While this practice maintains the familiar look of printed reports, it makes no use of hyperlinks; therefore, information cannot be indexed in search engines. In the second stage, companies disseminate information in HTML format and introduce hyperlinks. In the third stage, companies differentiate web-based from printed reporting; corporate websites support alternative ways to present complex information and allow to improve and expand information, thus divulging details that cannot be incorporated at low cost or effectively in hard-copy statements. Finally, they provide interactive information analysis tools. However, a risk of information overload may occur in this third stage.

Existing literature emphasises the advantages of web-based reporting for both companies and users:

- it is a cheap but powerful means of communication (Beattie \& Pratt, 2003; Khan \& Ismal, 2012): it eliminates both technological and cost constraints on the amount of information disclosed, thereby reducing information asymmetry not only between the company's insiders (typically, directors and managers) and external stakeholders, but also between domestic and foreign investors (Debreceny et al., 2002);

- it enables companies to divulge information to a much wider variety of stakeholders (Oyelere \& Kuruppu, 2016), without geographical boundaries (Aly et al., 2010) and on a real-time basis; particularly, small investors and professional analysts use the Internet as their main source of information (Sushila \& Amol, 2016);

- it replaces, or at least supplements, static with dynamic information (Sushila \& Amol, 2016);

- it makes it easier to collect data from a single source (Sushila \& Amol, 2016);

- it enables companies to archive historical information (Elsayed et al., 2010), which remains available to stakeholders for many years;

- it allows companies to customise information (Unerman \& Bennett, 2004);

- it provides rapid access to specific content meeting the stakeholders' information needs and preferences (Elsayed et al., 2010), by making use of pulldown menus, hyperlinks and search facilities (e.g. website map and search engine) (Oyelere \& Kuruppu, 2016); 
- it supports stakeholder engagement based on online dialogue (Elsayed et al., 2010; Rogate, 2017), which can be conducted within Internet-based communities, such as corporate forums arranged in the company's website.

\section{Accounting Perspectives on Web-Based Reporting}

Web-based reporting is mainly considered to be a type of voluntary disclosure; therefore, several theories largely adopted in accounting literature are useful to explain its spread (Shehata, 2014).

$\square$ According to agency theory, web-based reporting can be useful to mitigate the agency problem between managers and shareholders (Watson et al., 2002), especially in listed companies with largely dispersed ownership. While managers should act on behalf of shareholders, the former and the latter could have different interests. Therefore, managers disclose more voluntary information to prove that their decisions and behaviour are causing no harm to shareholders.

$\square$ Signalling theory posits that companies divulge information as a signal of their profitability (Oyeler, 2003), in order to distinguish themselves from other firms in the same market or industry. In this regard, the voluntary use of the Internet enables companies to demonstrate that there is no bad news to keep hidden from the stakeholders (Craven \& Marston, 1999). Voluntary web-based reporting is convenient to show that a company is performing better than its competitors; consequently, web-based reporting can strengthen a company's reputation and ability to attract investments. The final effect consists in the same level of voluntary disclosure for all the companies of the same industry, because none of them can risk being perceived as worse than any of the others.

$\square$ Through the lenses of institutional theory, the diffusion of web-based reporting is primarily explained by isomorphism (DiMaggio \& Powell, 1983). Companies sharing the same social field are subject to similar pressures, which typically come from the State and professional associations that have set explicit rules and implicit norms. In this regard, both explicit and implicit pressures for transparency can cause more web-based communication to go to stakeholders. Companies tend to conform to what is commonly deemed expected and successful conduct; they emulate each other in an effort to comply with the rules, norms, routines and belief systems prevailing in their environment (Suddaby, 2013). Compliance is indeed necessary to earn legitimacy for existing and working (Rankin et al., 2012).

$\square$ Following legitimacy theory (Suchman, 1995), we relate the spread of web-based reporting to the need for companies to demonstrate that 
they have been acting consistently with an explicit or implicit social contract based on society's values, norms and expectations. In other words, companies can disseminate information on their corporate websites to reach the public at large, and not only the shareholders; in doing so, they seek to gain, maintain or repair the legitimacy that is paramount to survive and operate (Milne and Patten, 2002). In particular, legitimacy theory has often been used to interpret the increasing disclosure of social and environmental issues.

$\square$ Stakeholder theory also comes in handy to examine the diffusion of web-based reporting. In short, stakeholder theory states that an organisation has relationships with different, but identifiable, stakeholders: shareholders, investors, employees, suppliers, customers, trade associations, political groups and communities (Freeman, 1984; Donaldson and Preston, 1995; Freeman \& McVea, 2001). Stakeholders provide the organisation with their approval, support and critical resources (Salvioni, 2002), which vary according to stakeholder category. Consequently, the managers' duty is to balance the interests of stakeholder groups and guide them towards the same direction, avoiding any trade-off among stakeholders (Freeman \& Dmytriyev, 2017). The extent to which managers will consider such interests depends on the power or influence each stakeholder group exercises over the resources the company needs: the more important the resources, the more attentive the managers will be (Rankin et al., 2012). Given the crucial role of stakeholder relationship management for lasting corporate success, managers should divulge information to show that the company's mission, strategies, activities and results meet the stakeholders' expectations: in doing so, they boost the stakeholders' trust and facilitate the company's access to resources. The Internet guarantees great opportunities of communication on financial, social and environmental matters that are meaningful to a company's stakeholders; in this regard, stakeholder theory especially contributes to explain the disclosure of voluntary information to stakeholders.

\section{Research Questions and Methodology}

In a global context increasingly affected by information technologies, acknowledging the key role that corporate communication plays in stakeholder relationship management stimulates the exploration of approaches to web-based integrated CSR reporting adopted by companies. In this regard, this study intends to answer the following research questions:

1. How do companies recognised as leaders in dealing with CSR matters use their websites to represent the integration of economic, social and environmental principles, policies and performance?

2. How does the usage of web-based tools affect the way companies communicate with their stakeholders? 
From a methodological perspective, this research applies content analysis to the World Wide Web. Content analysis is a research method that uses procedures to make valid inferences from text (Weber, 1990) and provide unbiased descriptions and explanations of phenomena (Neuendorf, 2017). This non-intrusive technique (Macnamara, 2005) allows for the gathering and investigating of text content, where content refers to words, pictures, symbols and ideas, and text is anything written, visual or spoken (Neuman, 1997).

Applying content analysis to the World Wide Web was initially a challenge for scholars, because it requires stability (Weber, 1990). Specifically, the results of content analysis should be invariant over time, but such a condition cannot be guaranteed when a website is investigated: indeed, the dynamism of the Internet makes it a moving target for communication research. In spite of this, content analysis has been largely adopted to investigate online communication, because its capability of coping with a large quantity of data provides advantages in terms of web analysis (McMillan, 2000).

In this study, content analysis was conducted on a significant sample of companies selected on the basis of their commitment to social and environmental issues. The chosen sample coincides with 2017 Fortune's "Change the World" list, which is composed of the first 50 companies with annual revenues of at least $\$ 1$ billion, ranked according to three criteria: measurable social impact, business results and degree of innovation. Combining such elements is necessary for adopting a company's orientation toward integrated CSR. In fact, contributing to the solution of social issues and introducing innovations enhance the company's image and reputation, which leads to a positive impact on profitability and shareholder satisfaction.

The sample had a mixed composition, including 33 publicly listed companies and 17 privately held ones, differing in size, country of origin and sector ${ }^{1}$.

Content analysis was carried out on each company's website. The investigation included the information contained in the homepage and in internal pages, excluding the commercial section of the website.

According to the a priori principle, an extensive list of items, i.e. information content, was compiled before starting the analysis, based on the existing literature (Xiao et al., 2004; Jose \& Lee, 2007; Aly et al., 2010; Elsayed et al., 2010; Sushila \& Amol, 2016) and the most important frameworks concerning CSR, sustainability and the disclosure of environmental, social and governance information (GBS, 2001; OECD, 2011; UNGC, 2015; Global Reporting Initiative, 2016). This list of items was initially tested on a small number of websites. This was necessary to determine whether the list covered all the typical CSR-related content divulged by companies. When further topics emerged, they were added to the original list.

Overall, the final list included 214 items, classified into seven categories: main website features and firm presentation (59 items); corporate governance (35 items); investor relations and financial information (20 items); social issues (37 items); environmental issues (16 items); audit of financial information and assurance of nonfinancial information (13 items); communication tools and website usability (34 items). 
Each item consisted in a small piece of information (i.e. a word or a short sentence), whose existence in the 50 corporate websites was verified by this writer through socalled human content analysis.

Unlike automatic text scanning, human content analysis provides high effectiveness to the investigation, thanks to the option of identifying an item through acceptable synonyms or similar phrases and meaning (Macnamara, 2005).

However, this is precisely why using human content analysis could also negatively affect reproducibility or intercoder reliability, which refers to the extent to which content classification produces the same results when the same text is coded by two or more observers (i.e. researchers) (Weber, 1990). In order to assure a satisfactory degree of intercoder reliability, a preliminary test was conducted by two observers this author and another research expert - who separately analysed a sub-sample composed of 5 out of the 50 "Change the World" companies' websites. Among the different measurement coefficients to assess intercoder reliability (Lombard et al., 2002), this study adopted the percent agreement index, which was selected in the light of its simple and intuitive nature and ease of calculation. A 90\% agreement emerged, which is considered acceptable in most situations (Neuendorf, 2002).

The remaining 45 corporate websites were all coded by this writer alone, aware that she was correctly applying the content analysis method.

Performing human content analysis for a large amount of items on numerous web pages was time-consuming; on average, it took about three hours to investigate each website, and the entire analysis was completed in six weeks during October and November 2017. Excel supported data collection and processing.

\section{Empirical Results}

This section describes the main results of the investigation ${ }^{2}$ with reference to 49 companies; lacking an English version, one website could not be analysed.

Most of the companies investigated kept their web-based reporting adequately updated; 44 websites had been updated at least once in the previous month, 3 in the previous quarter and 1 in the previous semester, while it was impossible to identify the latest update of 1 website. The companies demonstrate understanding of the stakeholders' need for updated information as a fundamental basis for decisionmaking. Indeed, most of the firms analysed use their website to disclose information continuously and at shorter intervals than is typical of traditional printed communications to shareholders and other stakeholders.

To be effective, web-based reporting must combine information content with the way it is presented and made available to Internet users, as explained below.

\subsection{Main Website Features and Firm Presentation}

Internet users who access a company's web-based reporting start getting information from the homepage. At the time of the analysis, many companies provided information not only in English, but also in other widely spoken languages, such as Spanish and Chinese $(24.5 \%)$ and in the language of their own country $(24.5 \%)$. Obviously, this choice contributes to expand the number of stakeholders 
who are potentially reached by web-based reporting, according to market globalisation rules.

To make navigation easier, most of the websites comprised specific tools, such as a search engine $(75.5 \%)$, a website map $(55.1 \%)$ and menus $(75.5 \%)$ to help users find the desired information.

Almost all the websites $(91.8 \%)$ contained terms and conditions about how to use the information provided by the company, while only half $(53.1 \%)$ specified disclaimers on reliability, correctness, completeness, accuracy and timeliness of webbased reporting information. Since a company's stakeholders should constantly receive this as a type of assurance, the lack of such statements could jeopardise the comprehensive effectiveness of online reporting.

A website should also be structured to promote further dialogue and exchange of information between a firm and its stakeholders; in this regard, the company should adopt ICT and Web 2.0 tools (Bosetti, 2015) to support innovative forms of communication. However, the analysis discovered that many websites provided traditional contacts (postal address, 65.3\%; telephone number, 79.6\%; email, 69.4\%), but only few of them provided Skype contacts $(2 \%)$, a chat room or a dialogue box (18.4\%) and discussion forums (6.1\%). Instead, all but 3 websites were connected to one or more official corporate profiles on social networks (with large prevalence of Facebook, Twitter, LinkedIn and YouTube), which can be considered as virtual places where the stakeholders can interact with both the company itself and their peers.

Web-based reporting can also serve as a bridge to other significant sources of information. In this respect, our investigation discovered the existence of links to the websites of two types of organisations. While very few listed companies provided links to websites of primary financial institutions and supervisors (e.g. the stock exchange and the securities and exchange commission), $51 \%$ of the sample directed their stakeholders towards the websites of important organisations they either cooperate with or support, which are engaged in social and environmental issues (e.g. UN Global Compact, UN Women, UNICEF, ILO and various national institutes). This is a concrete signal that companies are increasingly aware of the importance of sustainability for durable success and positive interaction with all the stakeholders.

The general presentation of the company, based on the homepage, also included several direct links to the internal sections of the website, focused on corporate governance $(40.8 \%)$, financial information (71.4\%), social matters $(32.7 \%)$, environmental impacts of activities (14.3\%) and sustainability in general (57.1\%).

Oddly enough, despite the growing attention of the "Change the World" companies to integrating social and environmental concerns into their strategies, 14 of them did not emphasise sustainability on their homepage. Most of the websites, however, specified the ethical values and business principles governing the company's decision-making, strategies, activities and evaluation processes (91.8\%). Moreover, $51 \%$ of the sample divulged a sustainability policy statement or other similar declarations (a statement of social policies, 18.4\%; a statement of environmental policies, 26.5\%; a stakeholder letter, 38.8\%; a document focused on the Sustainable Development Goals pursued by the firm, 24.5\%).

From the homepage, a company's stakeholders should also have the possibility to access detailed reports on corporate governance, directors' remuneration systems and 
financial, social and environmental performance. In this regard, our analysis discovered the availability of different types of reports ${ }^{3}$ and the predominance of PDF files over HTML, modifiable or technologically advanced formats (such as Excel, XML and XBRL).

\subsection{Corporate Governance}

Board-level decision-making determines how companies manage sustainability and interact with all their stakeholders in a responsible way (Salvioni et al., 2016). In this regard, our investigation proved the presence of information in HTML format i.e. immediately visible to Internet users - concerning the company's profile (95.9\%), mission $(83.7 \%)$ and aims and strategies $(65.3 \%)$. Moreover, our analysis found that $75.5 \%$ of the sample divulged their code of ethics online and that a separate code of conduct for directors and managers had been adopted and published on the website by $20.4 \%$ of the companies.

Specific details on the board composition $(85.7 \%)$, powers and functions (49\%), as well as the establishment of internal committees $(65.3 \%)$ were frequently disseminated in HTML format. Conversely, information on directors' remuneration systems was scarce, including for listed companies.

Information on the ownership structure often lacked, having been disclosed by only $36.7 \%$ of the sample, whereas information on shareholders' meetings were found more frequently, especially in the websites of listed companies ${ }^{4}$.

Descriptions of risk management $(18.4 \%)$ and internal control $(16.3 \%)$ were rarely presented in HTML format, in spite of their key role in the effective management of sustainability matters.

\subsection{Investor Relations and Financial Information}

One dimension of corporate responsibility deals with the equitable satisfaction of all the economic expectations converging on a firm's business. Similarly, the concept of sustainable development suggests a model of economic growth combined with social equality and environmental protection (Salvioni \& Bosetti, 2014b). Therefore, the debate on CSR and sustainability does not overlook the importance of profitability for company's success; rather, it presupposes that companies care about the financial interests of majority and minority shareholders and other investors and carry out operations according to principles of efficient use of resources and economic convenience.

Consequently, both publicly listed and private companies have an obligation to disclose financial information, which is also established by laws and regulations. The use of the Internet may favour the dissemination of different types of financial information, which only in part meet mandatory requirements. Web-based reporting can actually support investor relations (IR) management through the diffusion of further financial data, thus helping to enhance transparency in global capital markets. Moreover, corporate websites can serve as open-access archives where to keep financial documents of past years, so that they stay available to any shareholder, investor, analyst or other stakeholder who is interested in the evolution of a company's financial position and results over time. 
In this regard, our empirical investigation found that all the listed companies and 5 unlisted ones - together representing three fourths of the sample - divulged their most recent annual, half-year and quarterly financial statements online, as well as those of previous financial years. Financial highlights (typically in the form of ratios) and PDF or PowerPoint presentations of the company's financial situation and results were disseminated by essentially the same firms.

$87.8 \%$ of the firms also published their financial releases in the website; on the contrary, only $16.3 \%$ provided a financial press coverage and $30.6 \%$ showed credit ratings. Such communication choices seem to denote the intention of directing and controlling the information disclosed to the public, perhaps to prevent possible negative perceptions due to third-party opinions and evaluations.

As for the listed companies, our investigation verified the dissemination of further types of financial disclosures, suitable to meet more specific information needs. Among others, the current stock price and stock chart were provided by all but one of the listed firms; moreover, the stock chart was usually editable $(75.8 \%)$ to allow users to select a certain period of time or compare the company's trend with an index or a competitor's. In the same way, most of the websites included an investment calculator to quantify the current value of an equity interest (63.6\%). Finally, most of the listed companies' websites included IR FAQs (87.9\%), an analyst coverage (54.5\%) and IR traditional contacts (90.9\%), but no IR chat or IR Skype contact.

\subsection{Social Issues}

Effective integration of CSR in strategies and daily operations implies that companies have to fulfil their responsibilities towards society at large; in this regard, CSR includes charity, volunteering and ethical labour practices that are performed with the purpose of protecting the societal interests of communities, employees and customers (Freeman \& Dmytriyev, 2017).

All the companies comprised in the "Change the World" list have been recognised as successful from the social impact perspective. For this reason, our empirical investigation focused on a variety of aspects concerning corporate commitment and actions to improve people's quality of life.

In all firms, both listed and unlisted, large and small, a necessary premise should consist in identifying the stakeholders to interact with and understanding their societal needs. To this end, approximately one third of the sample provided a stakeholder map (34.7\%), a materiality matrix depicting the most significant issues in the company's management from an internal and an external point of view $(34.7 \%)$, as well as a description of the engagement practices and relationship management mechanisms the firm has adopted to conduct a proper dialogue with relevant stakeholders (e.g. questionnaires, focus groups, surveys, telephone calls and direct meetings) (38.8\%). Although all of this should help enhance the company's ability to create and distribute value to the stakeholders, only $18.4 \%$ of the web-based reports included information on value creation and distribution.

As concerns the commitment to improving employee conditions and make them more equitable and fair, $71.4 \%$ of the firms disseminated details on their policies on diversity and inclusion and related activities, while $61.2 \%$ provided information on the training, mentoring and learning programmes they had financed or organised to 
promote the advancement of their personnel's knowledge and skills. Furthermore, $32.7 \%$ of the websites contained a description of family-friendly policies and worklife balance methods adopted by the companies analysed, such as home and remote working and flexible schedule. $67.3 \%$ of the sample divulged information on the commitment to guaranteeing occupational health and safety, which sometimes was demonstrated by the dissemination of details on third-party certifications (e.g. OHSAS 18001 and OSHA) obtained by the companies (18.4\%). Information on personnel salaries and benefits (such as life and medical insurance, sick leave and a flex spending account for health or dependent care expenses) was divulged by $34.7 \%$ of the companies.

Web-based reporting can also contain information on supplier relations, when these are managed by a company in a way that encourages the diffusion of CSR in the supply chain, in the best interests of employees, customers and communities. $69.4 \%$ of the firms analysed placed emphasis on responsible and sustainable sourcing. Moreover, $55.1 \%$ declared their usage of social and environmental criteria (e.g. supplier compliance with ethical labour practices) to select, assess and audit their suppliers; in addition, $30.6 \%$ underlined that they offered training to their suppliers in order to strengthen their awareness of CSR and stimulate responsible behaviour.

Integrating societal interests in business operations also means meeting customer needs for safe, healthy and reliable products and services, as well as the particular necessities of disadvantaged and vulnerable people. This is a typical web-based reporting topic; indeed, $63.3 \%$ of the firms provided this type of information and an equal percentage described their commitment to $R \& D$ and introducing sustainable innovations into the market. CSR emphasises the impact of business decisions and activities on communities, in the local, national or supranational context. In this regard, most of the websites reported about respect of human rights (e.g. indigenous rights) $(57.1 \%)$, promotion or involvement in non-profit initiatives $(75.5 \%)$, donation of funds for supporting programmes and activities of NGOs, governments and citizens $(71.4 \%)$ and participation in anti-corruption programmes $(40.8 \%)$. Half of the companies also described, and sometimes estimated, the indirect economic impact of their activities, which normally consisted in job creation and infrastructure development (51\%). As regards the nature of the information divulged, the investigation discovered large use of qualitative descriptions (93.9\%), often supplemented by both non-financial $(77.6 \%)$ and financial KPIs $(57.1 \%)$ related to the company's social performance (for example, investment in employee training and money donated to non-profit initiatives). Certifications, recognitions and awards for the company's social commitment were disclosed in $65.3 \%$ of the web-based reports, whereas a press coverage on the firm's approach to sustainability was considerably less widespread than press releases $(14.3 \%$ vs. $51 \%)$. Finally, non-financial reporting in PDF and/or HTML format was usually divulged on an annual basis (67.3\%) and added to a web-based archive (59.2\%).

\subsection{Environmental Issues}

A company's ability to operate in an environmentally friendly manner has become a priority in many industries (Gaussin et al., 2013; Gandini et al., 2014). Environmental protection efforts by companies are indeed a significant part of CSR, 
in accordance with the expectations of society at large (Freeman \& Dmytriyev, 2017). The increasing interest in environmental issues has generated important consequences for the corporate governance, management and communication of all companies, regardless of their sector, size and, at least in part, ownership structure. The progressive spread of such environmental awareness has determined the appointment of corporate bodies with responsibilities over environmental matters; it has entailed a rethinking of $R \& D$, production and logistics (Severo et al., 2018), and it has also influenced the quantity and quality of environmental information disclosed by companies, also in compliance with stricter law requirements and best practices.

Attention on environmental management is confirmed by the results of our empirical investigation, which has verified the dissemination of content in HTML format. Although only few firms (12.2\%) provided online information on their committees and officers in charge of supervising, assessing and making decisions on processes with possible environmental impacts, a large majority of the websites (63.3\%) described the company's approach to environmental management. This often involved energy efficiency and renewable and clean energy (69.4\%), greenhouse gas emissions $(67.3 \%)$ and the climate change connected thereto $(40.8 \%)$, waste management $(59.2 \%)$, water consumption and treatment $(55.1 \%)$, as well as how to preserve biodiversity and ecosystems (32.7\%). Information on direct impacts generated by the activities of the company itself $(36.7 \%)$ prevailed over information on indirect impacts associated with the supply chain $(22.4 \%)$.

Information on environmental issues usually incorporated qualitative descriptions (71.4\%) and quantitative non-financial KPIs (63.3\%). Sometimes, such KPIs referred to the company's environmental footprint (Hoekstra, 2008; Čuček et al., 2012). A small number of companies also disseminated financial KPIs presenting a connection with environmental management (14.3\%); for example, investments and expenses aimed at protecting the environment.

As further assurance of the company's environmental commitment, a few webbased reports contained information about independent internal (16.3\%) and external audits $(22.4 \%)$ performed on processes with possible environmental effects. Moreover, $46.9 \%$ of the firms disseminated details about environmental certifications (e.g. EMAS, Ecolabel, ISO 14001, ISO 50001) and awards they had received.

\subsection{Audit of Financial Information and Assurance of Non-Financial Information}

Audit and assurance consist in third-party independent verification of a company's financial and non-financial reporting procedures and reports. Their purpose is to certify that the information divulged to the stakeholders is accurate, complete, reliable, trustworthy and consistent with generally accepted standards of financial and sustainability reporting (O’Dwyer, 2011; Haider \& Kokubu, 2015; Fazzini \& Dal Maso, 2016). An audit of financial information is a well-established process, carried out in compliance with the legislation that makes it mandatory for public companies and other types of firms. On the contrary, assurance of sustainability reporting has traditionally been voluntary, in line with the nature of this kind of information. By way of example, although Directive 2014/95/EU introduced some obligations 
regarding the assurance of non-financial information of large public-interest entities, the process still remains voluntary for all the other firms (Aureli et al., 2017; Venturelli et al., 2017).

According to such premises, our empirical investigation found that $75.5 \%$ of the companies divulged the auditor's report on their financial statements. The auditor's report was normally integrated in the same PDF file of the annual report. Only 3 companies also published the auditor's report in either an HTML page or a standalone PDF, so that it could be immediately noticed by Internet users.

As concerns assurance of non-financial information contained in sustainability, social and environmental reports, an assurance statement was found in half of the websites analysed; however, it appeared outside the report for just $24.5 \%$ of the companies. $8.2 \%$ of the sample also disseminated a short declaration of assurance in HTML, containing the most important details on the assurance provider and/or the procedure (e.g. assurance standards and guidelines adopted to validate the reports) ${ }^{5}$.

Unfortunately, no statement was found reassuring the stakeholders that an independent third-party verification had been performed in relation to the overall quality of the website, based on its accessibility, usability and timeliness of information.

\subsection{Communication Tools and Website Usability}

The effectiveness of web-based reporting depends not only on the amount, variety and degree of detail of the information disseminated, but also on the presentation format and tools that a company uses to disclose it (Nielsen, 1999; Yeung \& Law, 2006; Belanche et al., 2012; Bozcuk, 2012). Information readability, accessibility and comprehensibility are essential to make web-based reporting more appealing to stakeholders (FASB, 2000), whose website visit should be stimulated and facilitated with content searching, viewing and processing features. Therefore, usability refers to the speed and ease with which an Internet user finds and collects information from a website; the higher the usability, the more positive the user's experience (AlcántaraPilar et al., 2015).

Usability relates essentially to website design and appearance. In this regard, companies should bear in mind that different people could have different abilities and necessities; for this reason, the website should have a customisable format to support better navigation by anyone.

One of the features that affects usability is the option for Internet users to select font size, colours and contrast and make use of text-only mode navigation. However, our empirical investigation found that the companies included in the sample almost ignored the need for speedy and comfortable navigation throughout the website. On the contrary, they seemed to pay greater attention to other tools, such as bookmarks and allowing the user to add documents to a personal briefcase from where to download them all at once. In such cases, the companies seemed to emphasise the function of the website as an online archive.

Usability also implies the adoption of the same template (i.e. combination of colours, company logos, etc.) on all the pages of a website, to avoid confusing visiting stakeholders. Moreover, the text should be easily readable, with short paragraphs and simple sentences, and should have pictures and graphs in order to 
attract the stakeholder's attention; dynamic graphics can help to this end. Furthermore, optimising the website for navigation on mobile devices is a priority in today's context, as well as the option for stakeholders to download and install apps on their smartphones. The empirical results were satisfactory for almost all the items described, totalising percentages between approximately $70 \%$ and $90 \%$; the only exception regarded apps, which were available in $28.6 \%$ of the websites. Similarly, just few websites $(10.2 \%)$ provided the option to personalise the navigation according to the user's profile (e.g. shareholder, customer, employee) and interests.

As stated above, usability also depends on how the corporate website content is structured and divulged to make the information immediately understandable to the stakeholders. In this respect, the investigation focused on financial and non-financial disclosures with the purpose of verifying the qualitative and quantitative nature of information disseminated in HTML format, the degree of multimedia and the use of hyperlinks among pages.

As concerns financial information, most of the websites combined descriptions $(71.4 \%)$ and quantitative measures $(83.7 \%)$ with a considerable use of tables and charts. However, editable tables and charts (8.2\% and $32.7 \%$ respectively), in which the stakeholders could select the data according to their needs, were much less popular than fixed ones (57.1\% and $44.9 \%$ respectively). The use of audio files, such as conference calls and podcasts of shareholders' meetings $(63.3 \%)$, were more frequently provided than pictures (40.8\%) and videos (46.9\%). Our investigation rarely discovered the presence of hyperlinks for jumping from a page to another or moving within a text message to collect more details on the same topic (14.3\%). Conversely, the option to download various financial documents was widespread, but PDF, JPEG and other non-modifiable formats prevailed over Excel and other editable formats $(79.6 \%$ vs. $49 \%)$.

With respect to social and environmental issues, descriptions were more used than quantitative KPIs (93.9\% vs. 77.6\%); consistently with this, tables and charts were quite uncommon, particularly in editable formats, while there was a broad usage of pictures $(89.8 \%)$ and videos $(81.6 \%)$. The presence of hyperlinks was significant too (73.5\%), but still lower than the option to download sustainability, social or environmental reports $(83.7 \%)$ to deepen user knowledge of the company.

\section{Disclosure Indexes}

Studies on online reporting have frequently used disclosure indexes to summarise the results of empirical investigations (Xiao et al., 2004; Marston \& Polei, 2004; Aly et al., 2010; Agboola \& Salawu, 2012). Similarly, this article proposes a set of disclosure indexes based on the score attributed to each company analysed, according to the presence of the selected items within the website, compared to the highest score the company could have obtained if it had provided all the items. For each company, a disclosure index $\left(\mathrm{DI}_{j}\right.$, ranging between 0 and 1$)$ is calculated for each one of the seven categories of items described above, as well as for the comprehensive list of items, according to the following formula: $\mathrm{DI}_{j}=\frac{\sum_{i=1}^{n} X_{i j}}{n_{j}}$

where: $n_{j}$ is the number of items applicable to the $j$-th company ${ }^{6} ; X_{i j}=1$ if the item is disclosed; 0, otherwise. 
The disclosure index regarding "Main website's features and firm presentation" has a mean value of 0.421 , with a minimum of 0.186 and a maximum of 0.661 .

With reference to "Corporate governance", the disclosure index shows a mean value of 0.405 . The minimum is 0.030 , while the maximum is 0.886 . For just 8 companies the index is equal to or greater than 0.600 .

On average, the disclosure index for "Investor relations and financial information" is the highest one (0.561), even if 4 unlisted firms have a score equal to 0 . Excluding such companies, the minimum value is 0.125 for 3 firms, whereas the maximum value is 0.900 . Overall, half of the companies analysed, including 3 unlisted ones, show a value equal to or greater than 0.700 . Moreover, the index is usually higher for publicly traded companies than for privately held ones; this is in line with the stricter disclosure requirements imposed on the former.

As regards "Social issues", the disclosure index shows a mean value of 0.434 ; the minimum is 0.054 and the maximum is 0.757 , with only 13 companies exceeding 0.600 . The index never shows a value of 0 ; however, all unlisted companies but one have below average values.

The disclosure index for "Environmental issues" has also a mean value of 0.434 . The index is equal to 0 for 9 firms, including 2 listed ones, while 2 companies reach the value of 1 and just 6 other companies exceed 0.700 . The sector in which a company operates does not seem to affect its environmental disclosure index.

The limited amount of information on audit and assurance processes corresponds to very low values of the disclosure index; the mean is very low and equal to 0.148 , with the maximum of 0.462 and the minimum of 0 for 11 firms.

With respect to "Communication tools and website usability", the disclosure index shows a mean value of 0.465 , with minimum of 0.147 and maximum of 0.794 . On average, the index is greater for listed companies.

Finally, a comprehensive disclosure index summarises the results of the entire investigation beyond specific information categories. The comprehensive disclosure index for the whole sample shows a mean value of 0.423 . The best company reaches 0.668 , while the worst has a value equal to 0.124 (Figure 1).

Figure 1: Comprehensive Disclosure Index: Examples from the Sample Analysed

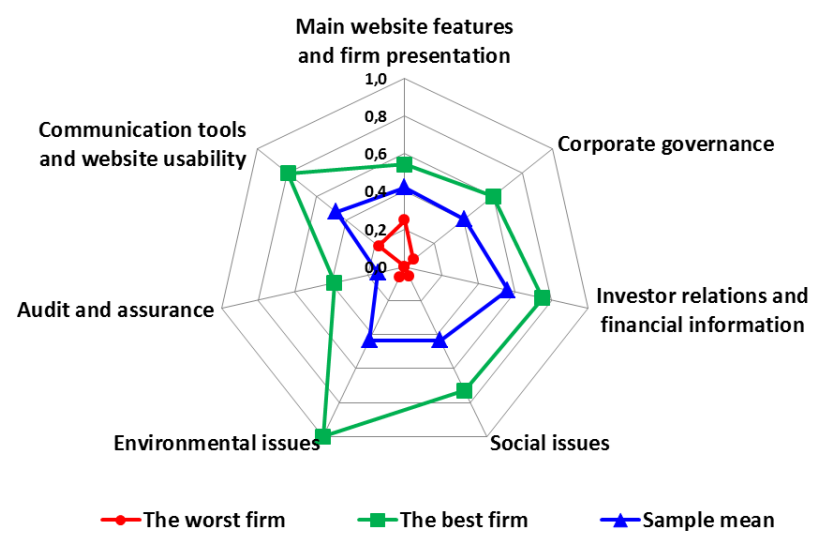




\section{Emerging Issues}

This study analysed the approach to online communication adopted by fifty companies recognised as CSR leaders. Despite the limited size of the sample, the empirical results support some concluding remarks.

Web-based reporting usually integrates details on corporate governance, including ethical principles and sustainability policies, with information on financial, social and environmental performance. Financial disclosure seems to be the most significant for both listed and unlisted companies; however, the quantity of items disseminated online with reference to the economic dimension of business is rather limited. Likewise, little is communicated in relation to social and environmental matters. In general, there is still a lot of room for improving the content of web-based reporting, as confirmed by the disclosure indexes presented in this article. Unfortunately, this is a disappointing issue that emerges from the investigation. Indeed, if even the CSR leaders neglect to represent how they reconcile social and environmental cares with the pursuit of profitability, it is quite improbable that other companies will effectively adopt an integrated approach to online communication.

Similarly, the companies analysed should enhance their presentation formats and tools, which influence the degree of web usability. For example, financial information could be enriched with multimedia files associated to the shareholders' meetings. In the same way, larger availability of editable charts and tables on economic, social and environmental performance could benefit the stakeholders, who could then process data according to their particular information needs.

In conclusion, this study contributes to expanding business literature on online communication of integrated CSR, by providing an insight into company's choices of information content and web usability. In addition, research findings can stimulate the intervention of policymakers and other regulators, such as the capital market authorities, in order to overcome the weaknesses that still exist in web-based reporting. According to institutional theory, significant advancement in the online disclosure of CSR matters may reasonably derive from the introduction of laws and recommendations with which companies would be obliged or induced to comply. As stated by legitimacy theory, a more effectively integrated communication on the financial, social and environmental dimensions of business would also help firms demonstrate their ability to create and share value with all the stakeholders, thereby gaining legitimation to operate in the long term.

\section{Bibliography}

Agboola, A. A., \& Salawu, M. K. (2012). The Determinants of Internet Financial Reporting: Empirical Evidence from Nigeria, Research Journal of Finance and Accounting, 3(11), 95-105.

Alcántara-Pilar, J. M., del Barrio-García, S., Porcu, L., \& Crespo-Almendros, E. (2015). Motivational Duality in Online Consumer Behaviour: Website Usability and Flow State as Moderating Factors, International Journal of Business and Economics, 14(1), 79-104.

Aly, D., Simon, J., \& Hussainey, K. (2010). Determinants of Corporate Internet Reporting: Evidence from Egypt, Managerial Auditing Journal, 25(2), 82-202.

http://dx.doi.org/10.1108/02686901011008972 
Aureli, S., Bosetti, L., \& Medei, R. (2017). Non-Financial Information Assurance. Do Italian Listed Companies Assure Sustainability Reports and/or Web Communications?, in Integrated Reporting and Non-financial Information Assurance. SMEs vs Large Firms, ASPI, 22-39.

Beattie, V., \& Pratt, K. (2003). Issues Concerning Web-Based Business Reporting: An Analysis of the Views of Interested Parties, British Accounting Review, 35(2), 155-187.

http://dx.doi.org/10.1016/S0890-8389(03)00016-7

Belanche, D., Casaló, L. V., \& Guinalíu, M. (2012). Website Usability, Consumer Satisfaction and the Intention to Use a Website: The Moderating Effect of Perceived Risk, Journal of Retailing and Consumer Services, 19(1), 124-132.

http://dx.doi.org/10.1016/j.jretconser.2011.11.001

Bisio, L. (2017). Transparency in Public Administrations: The Italian FOIA Case. Symphonya. Emerging Issues in Management (symphonya.unimib.it), 2, 7-18.

http://dx.doi.org/10.4468/2017.2.02bisio

Bosetti, L. (2015). Social Networks and Stakeholder Engagement. Evidence from Global Compact Lead Participants, Journal of Strategic and International Studies, 10(6), 44-56.

Bozcuk, A. E. (2012). Internet Financial Reporting: Turkish Companies Adapt to Change, Managerial Finance, 38(8), 786-800.

http://dx.doi.org/10.1108/03074351211239405

Brondoni, S. M. (2003). Network Culture, Performance \& Corporate Responsibility. Symphonya. Emerging Issues in Management (symphonya.unimib.it), 1, 8-24.

http://dx.doi.org/10.4468/2003.1.02brondoni

Brondoni, S. M. (2014). Global Capitalism and Sustainable Growth. From Global Products to Network Globalisation. Symphonya. Emerging Issues in Management (symphonya.unimib.it), 1, 10-31.

http://dx.doi.org/10.4468/2014.1.02brondoni

Cantino, V., \& Cortese, D. (2017). Integrated Report System: Purposes and Benefits of the Italian Law. Symphonya. Emerging Issues in Management (symphonya.unimib.it), 1, 83-94.

http://dx.doi.org/10.4468/2017.1.07cantino.cortese

Carroll, A. B. (1999). Corporate Social Responsibility: Evolution of a Definitional Construct, Business Society, 38, 268-295.

http://dx.doi.org/10.1177/000765039903800303

Cassano, R. (2017). Transparency and Social Accountability in School Management. Symphonya. Emerging Issues in Management (symphonya.unimib.it), 2, 19-30.

http://dx.doi.org/10.4468/2017.2.03cassano

Clarkson, M. B. E. (1995). A Stakeholder Framework for Analysing and Evaluating Corporate Social Performance, Academy of Management Review, 20(1), 92-117.

http://dx.doi.org/10.3138/9781442673496-013

Commission of the European Communities (2001). Green Paper: Promoting a European framework for Corporate Social Responsibility.

Crane, A., Matten, D., \& Spence, L. J. (eds.) (2008). Corporate Social Responsibility: Readings and Cases in Global Context. London: Routledge.

Craven, B. M., \& Marston, C.L. (1999). Financial Reporting on the Internet by Leading UK Companies, The European Accounting Review, 8(2), 321-33.

http://dx.doi.org/10.1080/096381899336069

Čuček, L., Klemeš, J. J., \& Kravanja, Z. (2012). A Review of Footprint Analysis Tools for Monitoring Impacts on Sustainability, Journal of Cleaner Production, 34, 9-20.

http://dx.doi.org/10.1016/j.jclepro.2012.02.036

Debreceny, R., Gray, G. L., \& Rahman, A. (2002). The Determinants of Internet Financial Reporting, Journal of Accounting and Public Policy, 21(4-5), 371-394.

http://dx.doi.org/10.1016/S0278-4254(02)00067-4 
DiMaggio, P. J., \& Powell, W. W. (1983). The Iron Cage Revisited: Institutional Isomorphism and Collective Rationality in Organizational Fields, American Sociological Review, 48(2), 147-160. http://dx.doi.org/10.2307/2095101

Donaldson, T., \& Preston, L. (1995). The Stakeholder Theory of the Corporation: Concepts, Evidence, and Implications, The Academy of Management Review, 20(1), 65-91.

http://dx.doi.org/10.2307/258887

Eccles, R. G., \& Krzus, M.P. (2010). One Report. Integrated Reporting for a Sustainable Strategy, Hoboken, New Jersey: John Wiley \& Sons.

Eccles, R. G., \& Serafeim, G. (2011). Accelerating the Adoption of Integrated Reporting, in De Leo, F. \& Vollbracht, M. (eds.), CSR Index 2011, InnoVatio Publishing Ltd.

European Commission (2011). A renewed EU strategy 2011-14 for Corporate Social Responsibility.

Elsayed, A. N., Elbeltagi, I. M., \& El-Masry, A. A. (2010). Online disclosure: An analysis of the Egyptian listed companies, Corporate Ownership \& Control, 8(1), 552-568.

http://dx.doi.org/10.22495/cocv8i1c5p6

Fazzini, M., \& Dal Maso, L. (2016). The Value Relevance of “Assured” Environmental Disclosure: The Italian Experience, Sustainability Accounting, Management and Policy Journal, 7(2), 225-245.

http://dx.doi.org/10.1108/SAMPJ-10-2014-0060

Freeman, R. E., \& Dmytriyev, S. (2017). Corporate Social Responsibility and Stakeholder Theory: Learning From Each Other. Symphonya. Emerging Issues in Management (symphonya.unimib.it), 2, 7-15.

http://dx.doi.org/10.4468/2017.1.02freeman.dmytriyev

Freeman, R. E. (1984). Strategic Management: a Stakeholder Approach. Boston: Pitman.

Freeman, R. E., \& McVea, J. (2001). A Stakeholder Approach to Strategic Management. Darden Business School Working Paper No. 01-02.

Friedman, M. (1970), The Social Responsibility of Firms is to Increase its Profits, New York Times Magazine.

Gandini, G., Bosetti, L., \& Almici, A. (2014). Risk Management and Sustainable Development of Telecommunications Companies. Symphonya. Emerging Issues in Management (symphonya.unimib.it), 2, 16-29.

http://dx.doi.org/10.4468/2014.2.03gandini.bosetti.almici

Gaussin, M., Hu, G., Abolghasem, S., Basu, S., Shankar, M. R., \& Bidanda, B. (2013). Assessing the Environmental Footprint of Manufactured Products: A Survey of Current Literature, International Journal of Production Economics, 146(2), 515-523.

http://dx.doi.org/10.1016/j.ijpe.2011.12.002

GBS (2001). Social Reporting Standards. Milan.

Global Reporting Initiative (2016). Consolidated Set of GRI Sustainability Reporting Standards. Amsterdam, The Netherlands.

Gnecchi, F. (2006). Corporate Governance Communications. Symphonya. Emerging Issues in Management (symphonya.unimib.it), 1, 47-61.

http://dx.doi.org/10.4468/2006.1.04gnecchi

Haider, M. B., \& Kokubu, K. (2015). Assurance and Third-Party Comment in Sustainability Reporting in Japan: A Descriptive Study, International Journal of Environment and Sustainable Development, 14(3), 207-230. http://dx.doi.org/10.1504/IJESD.2015.070133

Henriques, A., \& Richardson, J. (eds.) (2004). The Triple Bottom Line: Does it All Add Up? London: Earthscan.

Hoekstra, A. Y. (2008). Water Neutral: Reducing and Offsetting the Impacts of Water Footprints. Value of Water Research Report Series No. 28, UNESCO-IHE. Delft, The Netherlands.

IASC (1999). Business Reporting on the Internet. London. 
Lopes, I. T. (2014). Key Performance Indicator Disclosures Through the Internet: Towards an Integrated Scoreboard, Social Technologies, 4(1), 37-50.

http://dx.doi.org/10.13165/ST-14-4-1-03

Jose, A., \& Lee, S.-M. (2007). Environmental Reporting of Global Corporations: A Content Analysis Based on Website Disclosures, Journal of Business Ethics, 72(4), 307-321.

http://dx.doi.org/10.1007/s10551-006-9172-8

Khan, M. N. A. A., \& Ismail, N. A. (2012). A Review of E-Financial Reporting Research. Journal of Internet and e-Business Studies, 4(4), 1-14.

http://dx.doi.org/10.5171/2012.798113

Klettner, A., Clarke, T., \& Boersma, M. (2014). The Governance of Corporate Sustainability: Empirical Insights into the Development, Leadership and Implementation of Responsible Business Strategy. Journal of Business Ethics, 122(1), 145-165.

http://dx.doi.org/10.1007/s10551-013-1750-y

Lambin, J. J. (2014). Rethinking the Market Economy. Symphonya. Emerging Issues in Management (symphonya.unimib.it), 2, 4-15.

http://dx.doi.org/10.4468/2014.2.02lambin

Lombard, M., Snyder-Duch, J., \& Bracken, C. C. (2002). Content Analysis in Mass Communication: Assessment and Reporting of Intercoder Reliability. Human Communication Research, 28(4), $587-$ 604.

http://dx.doi.org/10.1111/j.1468-2958.2002.tb00826.x

Macnamara, J. (2005). Media content analysis: Its uses, benefits and best practice methodology. Asia Pacific Public Relations Journal, 6(1), 1-34.

Marston, C. L., \& Polei, A. (2004). Corporate Reporting on the Internet by German Companies. International Journal of Accounting Information System, 5(3), 285-311.

http://dx.doi.org/10.1016/j.accinf.2004.02.009

McMillan, S. J. (2000). The Microscope and the Moving Target: The Challenge of Applying Content Analysis to the World Wide Web, Journalism \& Mass Communication Quarterly, 77(1), 80-98. http://dx.doi.org/10.1177/107769900007700107

Milne, M. and Patten, D. (2002). Securing Organisational Legitimacy: An Experimental Decision Case Examining the Impact of Environmental Disclosures. Accounting, Auditing \& Accountability Journal, 15(3), 372-405.

http://dx.doi.org/10.1108/09513570210435889

Mosca, F., \& Civera, C. (2017). The Evolution of CSR: An Integrated Approach. Symphonya. Emerging Issues in Management (symphonya.unimib.it), 1, 16-35.

http://dx.doi.org/10.4468/2017.1.03mosca.civera

Mosca, F., Tamborrini, P., \& Casalegno, C. (2015). Systemic Design: How to Compete by Leveraging the Value System. Symphonya. Emerging Issues in Management (symphonya.unimib.it), 2, 42-56.

http://dx.doi.org/10.4468/2015.2.04mosca.tamborrini.casalegno

Neuendorf, K. A. (2002). The Content Analysis Guidebook. Thousand Oaks, CA: Sage.

Neuendorf, K. A. (2017). The Content Analysis Guidebook, $2^{\text {nd }}$ edition. USA: Sage.

Neuman, W. (1997). Social Research Methods: Qualitative and Quantitative Approaches. Needham Heights, MA: Allyn \& Bacon.

Nielsen, J. (1999). Designing Web Usability: The Practice of Simplicity. Thousand Oaks, CA, USA: New Riders Publishing.

O'Dwyer, B. (2011). The Case of Sustainability Assurance: Constructing a New Assurance Service, Contemporary Accounting Research, 28(4), 1230-1266.

http://dx.doi.org/10.1111/j.1911-3846.2011.01108.x

OECD (2011). OECD Guidelines for Multinational Enterprises, OECD Publishing. http://dx.doi.org/10.1787/9789264115415-en 
Oyelere, P. B., \& Kuruppu N. T. (2016). Corporate Characteristics of Listed Companies Engaging in WebBased Financial Reporting in Emerging Economies, Corporate Ownership \& Control, 13(4), 66-80. http://dx.doi.org/10.22495/cocv13i4p7

Rankin, M., Stanton, P., McGowan, S., Ferlauto, K., \& Tilling, M. (2012). Contemporary Issues in Accounting. Milton, Queensland: John Wiley \& Sons Australia.

Rogate, C. (2017). Sharing Responsibilities for Sustainable Development. Symphonya. Emerging Issues in Management (symphonya.unimib.it), 1, 66-82.

http://dx.doi.org/10.4468/2017.1.06rogate

Salvioni, D. M. (2002). Transparency Culture and Financial Communication. Symphonya. Emerging Issues in Management (symphonya.unimib.it), 2, 22-33.

http://dx.doi.org/10.4468/2002.2.04salvioni

Salvioni, D. M. (2003). Corporate Governance and Global Responsibility. Symphonya. Emerging Issues in Management (symphonya.unimib.it), 1, 2003, 44-54.

http://dx.doi.org/10.4468/2003.1.05salvioni

Salvioni, D. M., \& Astori, R. (2013). Sustainable Development and Global Responsibility in Corporate Governance. Symphonya. Emerging Issues in Management (symphonya.unimib.it), 1, 28-52. http://dx.doi.org/10.4468/2013.1.03salvioni.astori

Salvioni, D. M., \& Bosetti, L. (2014a). Stakeholder Engagement and Integrated Reporting: Evidence From the Adoption of the IIRC Framework, Journal of Strategic and International Studies, 9(3), 78-89.

Salvioni, D. M., \& Bosetti, L. (2014b). Sustainable Development and Corporate Communication in Global Markets. Symphonya. Emerging Issues in Management (symphonya.unimib.it), 1, 1-19.

http://dx.doi.org/10.4468/2014.1.03salvioni.bosetti

Salvioni, D. M., Gennari, F., \& Bosetti, L. (2016). Sustainability and Convergence: The Future of Corporate Governance Systems? Sustainability, 8(11): 1203.

http://dx.doi.org/10.3390/su8111203

Severo, E. A., de Guimarães, J. C. F., \& Henri Dorion, E. C. (2018). Cleaner Production, Social Responsibility and Eco-Innovation: Generations' Perception for a Sustainable Future, Journal of Cleaner Production, 186, 91-103.

http://dx.doi.org/10.1016/j.jclepro.2018.03.129

Sharma, N. (2013). Web-Based Disclosures and Their Determinants: Evidence from Listed Commercial Banks in Nepal, Accounting and Finance Research, 2(3), 1-13.

http://dx.doi.org/10.5430/afr.v2n3p1

Shehata, N. F. (2014). Theories and Determinants of Voluntary Disclosure, Accounting and Finance Research, 3(1), 18-26.

http://dx.doi.org/10.5430/afr.v3n1p18

Suchman, M. C. (1995). Managing Legitimacy: Strategic and Institutional Approaches, Academy of Management Journal, 20(3), 571-610. http://dx.doi.org/10.5465/AMR.1995.9508080331

Suddaby, R. (2013). Institutional Theory, in Kessler, E.H. (ed.), Encyclopedia of Management Theory, Volume One. SAGE: USA.

Sushila, S., \& Amol, D. (2016). A Study of Corporate Web-Based Reporting in Hotel Industry. Asian Economic and Financial Review, 6(11), 661-680. http://dx.doi.org/10.18488/journal.aefr/2016.6.11/102.11.661.680

Unerman, J., \& Bennett, M. (2004). Increased Stakeholder Dialogue and the Internet: Towards Greater Corporate Accountability or Reinforcing Capitalist Hegemony? Accounting, Organizations and Society, 29(7), 685-707.

http://dx.doi.org/10.1016/j.aos.2003.10.009

UNGC (2015). The Ten Principles of the UN Global Compact. 
Venturelli, A., Caputo, F., Cosma, S., Leopizzi, R., and Pizzi, S. (2017). Directive 2014/95/EU: Are Italian Companies Already Compliant? Sustainability, 9(8): 1385.

http://dx.doi.org/10.3390/su9081385

Watson, A., Shrives, P., \& Marston, C. (2002). Voluntary Disclosure of Accounting Ratios in the UK, British Accounting Review, 34(4), 289-313.

http://dx.doi.org/10.1006/bare.2002.0213

Weare, C., \& Lin, W. (2000). Content Analysis of the World Wide Web. Opportunities and Challenges, Social Science Computer Review, 18(3): 272-292.

http://dx.doi.org/10.1177/089443930001800304

Weber, R. (1990). Basic content analysis (2 ${ }^{\text {nd }}$ edition). Newbury Park, CA: Sage.

Xiao, J. Z., Yang, H., \& Chow, C. W. (2004). The Determinants and Characteristics of Voluntary Internet-Based Disclosures by Listed Chinese Companies, Journal of Accounting and Public Policy, 23(3), 191-225.

http://dx.doi.org/10.1016/j.jaccpubpol.2004.04.002

Yeung, T. A., \& Law, R. (2006). Evaluation of Usability: A Study of Hotel Web Sites in Hong Kong, Journal of Hospitality \& Tourism Research, 30(4), 452-473.

http://dx.doi.org/10.1177/1096348006290115

\section{Notes}

${ }^{1}$ In 2017, Fortune's "Change the World" list included 22 companies with headquarters in the US, 13 in Europe, 9 in Asia, 3 in Australia, 2 in Latin America and 1 in South Africa. The following sectors were represented: technology (13), industrials (9), financials (7), food (6), health care (3), business services (3), retailing (3), transportation (3), hotels, restaurants and leisure (2), and energy (1). Some companies were larger than others and 19 of them also appeared in 2017 Fortune's Global 500 list. For the complete list of the 50 "Change the World" companies, see http://fortune.com/change-theworld/list/ [Accessed 26 April 2018].

${ }^{2}$ The complete list of items and all the detailed results can be requested to the author.

${ }^{3}$ As concerns the standards of non-financial reporting, the GRI Standards and Guidelines (59.2\%) largely prevailed over the IIRC Framework (6.1\%) and the AA1000 AccountAbility Principles (2\%). $10.2 \%$ of the companies adopted a tailor-made reporting methodology.

${ }^{4}$ Proxy statements (or notices of shareholders' meetings) were divulged online by $90.9 \%$ of the listed companies investigated and by 2 unlisted firms. Minutes of shareholders' meetings and/or voting results were disseminated by $39.4 \%$ of the listed companies.

${ }^{5}$ The investigation discovered a prevailing use of ISAE 3000 standard (30.6\%) to assure sustainability reporting. AA 1000 Assurance Standard (6.1\%) and other highly specific guidelines (e.g. those for validating data on greenhouse gas emissions) were also adopted (14.3\%).

${ }^{6}$ The number of items applicable to each company usually coincides with the total number of items included in the selected information category. Exceptions are applied when the disclosure index must reflect the different communication requirements imposed to publicly listed companies and privately held companies. Consequently, in some cases, $n_{j}$ is higher for the listed firms. 